\title{
MIDAS
}

Museus e estudos interdisciplinares

$10 \mid 2019$

Varia

\section{Arquitetura de museus no Brasil contemporâneo: diálogos entre tempos e lugares}

Museum architecture in contemporary Brazil: dialogues between times and places

Ivo Renato Giroto

\section{OpenEdition}

\section{Journals}

\section{Edição electrónica}

URL: http://journals.openedition.org/midas/1729

DOI: $10.4000 /$ midas. 1729

ISSN: 2182-9543

\section{Editora:}

Alice Semedo, Paulo Simões Rodrigues, Pedro Casaleiro, Raquel Henriques da Silva, Ana Carvalho

\section{Refêrencia eletrónica}

Ivo Renato Giroto, « Arquitetura de museus no Brasil contemporâneo: diálogos entre tempos e lugares », MIDAS [Online], 10 | 2019, posto online no dia 31 maio 2019, consultado no dia 16 junho 2019. URL : http://journals.openedition.org/midas/1729; DOI : 10.4000/midas.1729

\section{Este documento foi criado de forma automática no dia 16 Junho 2019.}

\section{c) (1)(2)}

Midas is licensed under a Creative Commons Attribution-NonCommercial-ShareAlike 3.0 International License 


\title{
Arquitetura de museus no Brasil contemporâneo: diálogos entre tempos e lugares
}

\author{
Museum architecture in contemporary Brazil: dialogues between times and \\ places
}

Ivo Renato Giroto

\section{NOTA DO EDITOR}

Artigo recebido a 19.08.2018

Aprovado para publicação a 15.03.2019

\section{Introdução: diálogos entre o passado e o presente}

1 Nas duas décadas quase completas do século XXI, assiste-se no Brasil a um notável aumento numérico de novos projetos arquitetónicos para museus, cuja visibilidade só encontrou paralelo na profusão de obras arquitetónicas para grandes infraestruturas desportivas destinadas à Copa do Mundo de 2014 e às Olimpíadas de 2016. Entre 2000 e 2018, 55 obras de museus de todos os tipos e escalas foram publicadas pela Projeto, a revista especializada em arquitetura de maior circulação no Brasil, contra apenas dez obras publicadas nos últimos 15 anos do século XX. Além de dar a medida do interesse por novos projetos para museus, o aumento exponencial do número de publicações revela uma presença inédita de edifícios de grande escala e de imagem icónica. ${ }^{1} \mathrm{O}$ facto parece indicar a entrada do Brasil na "era dos museus", fenómeno que o crítico e historiador de arquitetura Josep Maria Montaner identificou a partir dos anos de 1980 na Europa e nos Estados Unidos, uma vez consolidada a cultura pós-moderna do ócio e da indústria cultural de massas. A partir de então, o mundo desenvolvido assistiu a um expressivo 
movimento de expansão de museus e centros culturais para atender a um tempo de afluência massiva de visitantes (Montaner 2003, 8).

2 O êxito do Centro Georges Pompidou, obra dos arquitetos Renzo Piano e Richard Rogers (1970-1977) inaugurada em 1977 na então deprimida região do Marais, em Paris, indicava o início de um período marcado pela implementação de políticas públicas que anteriormente seriam consideradas "supérfluas", como a cultura e a revitalização de lugares de significado histórico-cultural.

3 Por volta da mesma época, o Brasil apresentava um cenário socioeconómico radicalmente diferente. A partir da instauração da ditadura militar em 1964, apenas honrosas exceções no campo cultural emergiram entre as grandes obras de infraestruturas impulsionadas durante os anos de repressão política e cultural. Em parte, isso refletiu o sucessivo desinteresse dos governantes pela arquitetura que, a partir do fim da epopeia de Brasília e da instalação dos militares no poder, viu a sua importância como ativo cultural nacional ser gradativamente diminuída. A grande maioria dos governantes brasileiros não investiu na significação icónica e simbólica da arquitetura, como fizeram os "estadistasbenfeitores” brasileiros Getúlio Vargas (1882-1954) e Juscelino Kubitscheck (1902-1976) e, mais recentemente, François Miterrand (1916-1996), em Paris (Segre 2003, 15-16).

4 Em meados da década de 1980, o contexto de redemocratização e de aguda crise económica contribuíram para postergar o início da "era dos museus" brasileira para o século seguinte. Assim como havia ocorrido na Europa em anos anteriores, entre os novos projetos para museus no Brasil observa-se um crescente protagonismo da arquitetura frente aos seus acervos ou exposições, algo que Rosalind Krauss, crítica de arte, identificou, ainda em 1990, a partir da ênfase na carga estética e experiencial presente na «lógica cultural dos museus no capitalismo tardio» (Krauss 1990, 7).

5 Na contemporaneidade, para além da finalidade específica de um museu, o seu potencial representativo e simbólico passou a ser usado como estratégia de requalificação urbana e como vantagem na competição global travada entre as cidades por visibilidade e turismo.

6 Ainda pouco estudada, a produção recente de museus em território brasileiro espelha as transformações, as renovações e as permanências que caracterizam o panorama contemporâneo do país. Neste início de século destaca-se a peculiar convivência entre museus projetados por arquitetos provenientes de diferentes gerações e contextos culturais diversos: ícones da arquitetura moderna brasileira dividiram espaço com arquitetos formados a partir do último quartel do século $\mathrm{XX}$, e juntos assistiram a um conjunto de intervenções no Brasil de arquitetos de renome internacional.

7 Este artigo sintetiza a complexidade dos discursos e dos diálogos travados entre gerações, referências e culturas arquitetónicas no Brasil atual, através da análise de cinco obras arquitetónicas destinadas a espaços museológicos, que pela sua importância e repercussão são aqui considerados como exemplares privilegiados das principais tendências e desafios que se colocam às instituições culturais do país. São analisadas as seguintes obras de arquitetura: o Museu Oscar Niemeyer (2001-2002), em Curitiba, da autoria de Oscar Niemeyer; o Instituto Moreira Salles (2012-2017), em São Paulo, projetado por Andrade Morettin; o Museu do Pão (2005-2007), em Ilópolis (Rio Grande do Sul), desenhado pelo escritório Brasil Arquitetura; a sede da Fundação Iberê Camargo (1998-2008), em Porto Alegre, da autoria de Álvaro Siza Vieira; e o Museu do Amanhã (2009-2015), no Rio de Janeiro, concebido por Santiago Calatrava. 


\section{O Museu Oscar Niemeyer (Curitiba): diálogos anteriores}

Entre as obras de maior importância e visibilidade da arquitetura brasileira no início do século XXI, figuram encomendas confiadas a consagrados arquitetos pertencentes à geração moderna, como Oscar Niemeyer e Paulo Mendes da Rocha. Formados sob os preceitos da modernidade, ambos tratavam o programa de necessidades como pretexto para a idealização de edifícios em intenso diálogo com a cidade e com a paisagem. Com trajetórias premiadas e internacionalmente reconhecidas, os longevos arquitetos Niemeyer faleceu em 2012 com quase 105 anos, enquanto o nonagenário Mendes da Rocha segue bastante atuante - figuraram entre as principais personalidades da arquitetura brasileira no início do século XXI, quando puseram à prova a vigência de pensamentos forjados ao longo do século passado.

No refluxo das experiências pós-modernas observou-se um importante movimento de revalorização das suas obras. Niemeyer foi agraciado com o prémio Pritzker de arquitetura em 1988 e a obra de Mendes da Rocha abriu um novo ciclo de protagonismo a partir do projeto para o MuBE - Museu Brasileiro da Escultura e Ecologia (1986-1995), em São Paulo. Em 2003, o quase centenário arquiteto carioca foi convidado para desenhar o pavilhão da Serpentine Gallery, em Londres, enquanto o paulistano começava a acumular os mais importantes prémios de arquitetura, entre estes o Pritzker de 2006.

Para ambos, o reconhecimento redundou num sensível aumento do número de encomendas para obras icónicas, dentre as quais se destacam os equipamentos culturais. Com efeito, na primeira década do século XXI, metade dos projetos desenvolvidos por Niemeyer tinham uma finalidade cultural, ante uma média de pouco mais de um sexto do início da sua carreira, em 1935, até ao final do século XX.

11 O museu que recebeu o nome de Niemeyer em Curitiba, inaugurado em 2002, revela como o uso de estratégias projectuais consolidadas ao longo da obra de um arquiteto pode assumir resultados e significados distintos ao longo do tempo. Desenhado a convite do então governador do Estado do Paraná, o arquiteto Jaime Lerner, o projeto pretendia dotar Curitiba, a capital do Paraná, de um museu de arte capaz de incluir a cidade no roteiro artístico nacional.

Para tanto, foi atribuída a Niemeyer a tarefa de converter em museu um antigo edifício que este arquiteto havia projetado em 1967 para uma instituição escolar e que, inaugurado em 1978, nunca chegou a abrigar a função para a qual havia sido concebido. Para dotar de simbolismo o austero edifício preexistente, um grande bloco horizontal branco, cego e suspenso por um conjunto de colunas em tronco de pirâmide, concebeu um novo volume independente do antigo, de caráter marcadamente escultórico, cuja forma evoca um olho humano estilizado sobre uma torre-pedestal (fig. 1 e 2). 


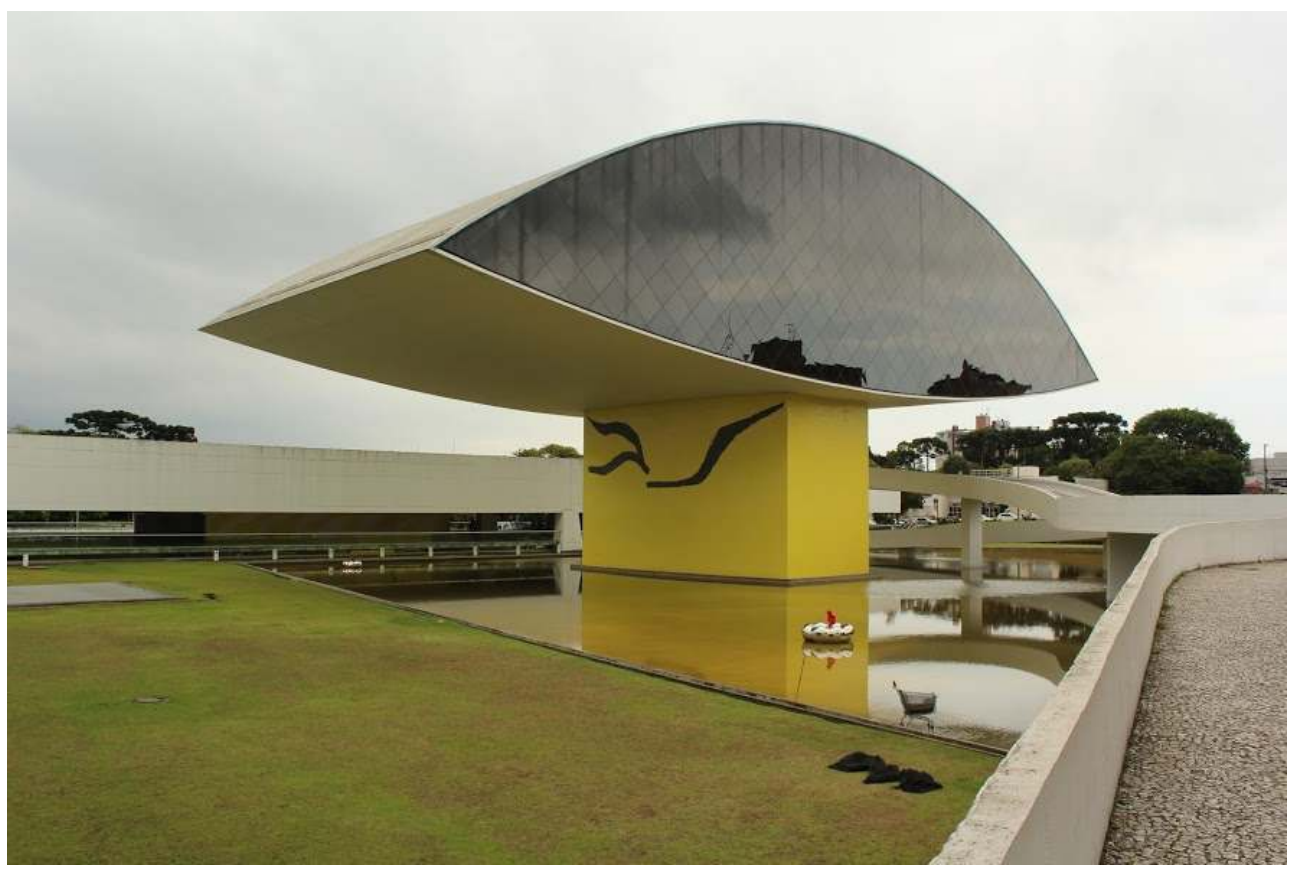

Fig. 1 - Vista externa da torre do "Olho", Museu Oscar Niemeyer, Curitiba, 2017 (C) Ivo Renato Giroto

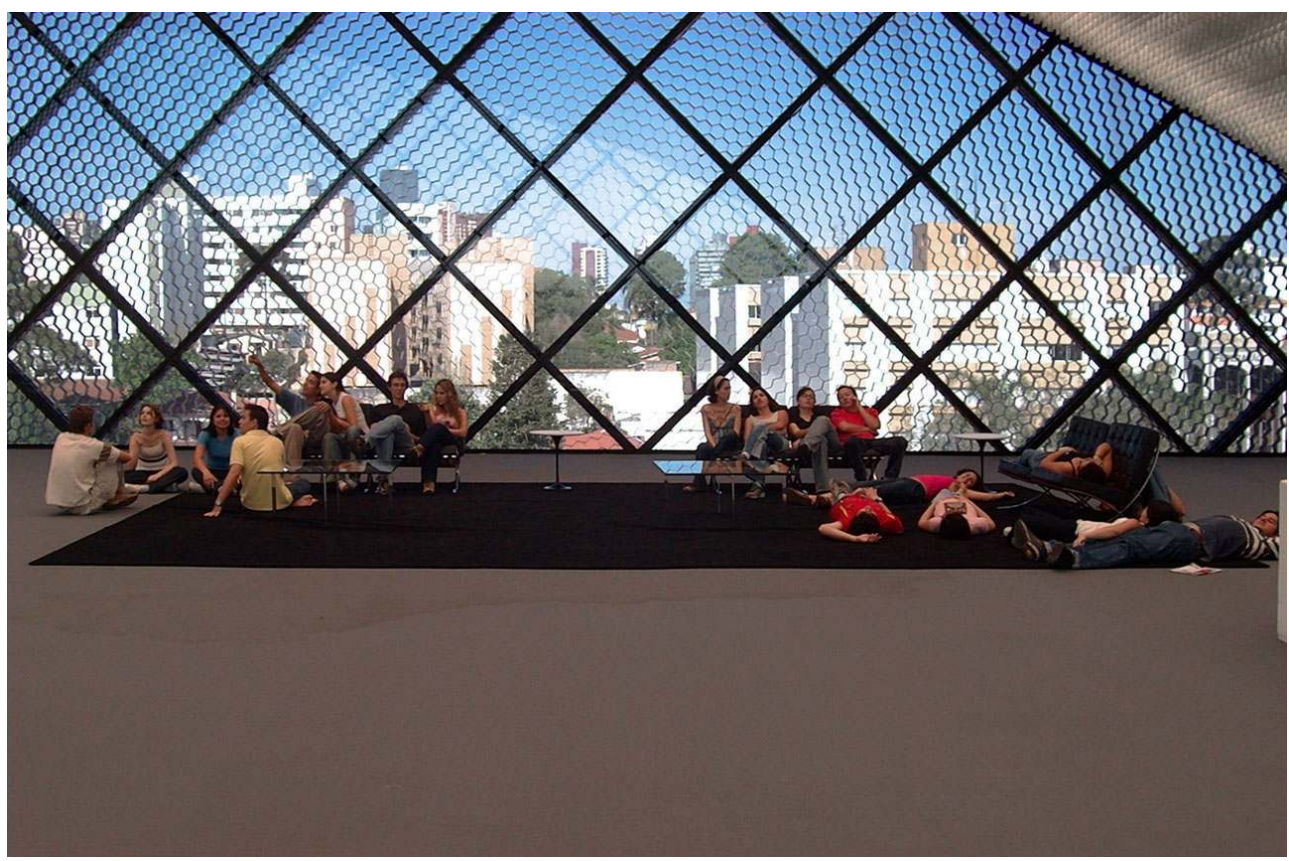

Fig. 2 - Vista interna da torre do "Olho", Museu Oscar Niemeyer, Curitiba, 2003

(c) Cortesia de Hugo Segawa

13 Célebre pela sua capacidade de criar potentes símbolos coletivos, Niemeyer concentrou-se no desenho do novo complemento, delegando aos arquitetos Francisco Fanucci e Marcelo Ferraz, do escritório Brasil Arquitetura, a tarefa de adaptar os espaços do antigo edifício a museu.

O primeiro ponto digno de nota é o uso de estratégias de projeto recorrentes na obra de Niemeyer, como a constante recombinação de elementos pertencentes a um repertório formal fechado. No projeto arquitetónico do museu, conhecido como MON (Museu Oscar 
Niemeyer), destaca-se a presença de um edifício escultural como complemento a um corpo funcional discreto, a partir da suspensão do volume principal sobre apenas um ponto de apoio. A estratégia, concebida no projeto para um museu em forma de pirâmide invertida em Caracas (1954), foi materializada pela primeira vez no Museu de Arte Contemporânea de Niterói (1996), cujo volume em forma de cálice parece pousar sobre um promontório rochoso nas margens da Baía de Guanabara, no Rio de Janeiro.

o número finito de elementos e de estratégias compositivas, constantemente aplicadas e recombinadas, que define o sistema compositivo de Niemeyer indica a prevalência da forma sobre a função. Pelo mesmo motivo, os elementos do seu repertório "clássico" não possuem significados definidos, sendo rearranjados em casos distintos para finalidades variadas (Mahfuz 2010, 293-294). No entanto, a ênfase plástica e monumental que caracteriza os projetos de Niemeyer não representa uma mera inclinação frívola, mas forma parte de uma intenção subjacente de criar no Brasil os símbolos sociais representados pelos monumentos ancestrais que visitou na Europa pela primeira vez em 1954 (Bruand 2002, 183-184).

16 Na obra madura do arquiteto, ainda que a repetição das suas conhecidas famílias formais indicassem o relativo esgotamento de uma linguagem outrora exitosa, o fascínio popular causado pela inconfundível torre do "Olho", rapidamente transformada em símbolo preferencial da cidade, demonstrou que o potencial simbólico da sua arquitetura permanecia intacto. Ao vagar entre o abstrato e o figurativo, (con)fundindo desenho e obra construída, os seus edifícios exploravam ao máximo as características visuais e escultóricas, apresentando-se eles mesmos como obra de arte.

17 A opção pela expressividade arquitetónica obrigou, muitas vezes, a museografia a adaptar-se ao espaço resultante. A abertura visual do "Olho" ao exterior gerou problemas de controle da incidência de luz natural, além da exuberância espacial e a vista da paisagem disputarem com as obras expostas a atenção do visitante. Na avaliação de Paulo Herkenhoff, um dos mais eminentes curadores, historiadores e críticos de arte brasileiros:

[É] inútil esperar que fosse um prédio para a arte. Tudo ali se constrange, se atemoriza ou pede autorização para uma provisória presença, pede desculpas pela perturbação da grandeza arquitetónica. O Olho é o poder da arquitetura. No entanto, finalmente há uma vingança da arte. Sem a arte, o Olho se torna um mirante e um edifício antropomórfico vulgar. A arquitetura de Niemeyer pode ser um puro ato poético de volúpia espacial. (Herkenhoff 2008, 67)

Outrora suporte da consolidação de uma identidade nacional, as obras de Niemeyer passaram a atuar como âncora de estratégias urbanas baseadas no estímulo ao consumo cultural e ao turismo de massas. Na esteira do sucesso do Museu de Arte Contemporânea que havia colocado Niterói no mapa turístico do Rio de Janeiro, a idealização do MON também buscava impulsionar a imagem de Curitiba, que inclusive valeu-se do projeto para entrar, em 2001, na concorrência para receber a malograda sede brasileira de um museu Guggenheim.

19 A potência formal que forjara os símbolos do Brasil moderno parecia ajustar-se às novas demandas comunicativas da arquitetura desde a pós-modernidade. Como observa Fernando Diez, o arquiteto Niemeyer:

Intuiu como ninguém o signo da nova época, e pode-se dizer que foi ele quem conseguiu converter a arquitetura ao sistema de comunicação de massas, antecipando-se por várias décadas ao fenômeno que o final do século viu se globalizar da mão de Thomas Krens e Frank Ghery com o Guggenheim de Bilbao. (Diez 2009, 34) 
Comeito, o Museu de Arte Contemporânea de Niterói é considerado no Brasil o marco inicial desse tipo de estratégia, que se vale deliberadamente da cultura como instrumento de marketing urbano. Ligeiramente anterior ao museu basco inaugurado em 1997 - o Museu Guggenheim em Bilbau -, o volume escultórico inserido na paisagem da Baía de Guanabara indicava um alinhamento com as estratégias em curso no mundo desenvolvido, que provavelmente só não tomou dimensões maiores devido às restrições económicas do Brasil de então.

21 As formas simbólicas e o amplo reconhecimento transformaram o nome do arquiteto comunista em marca cobiçada por políticos de vários espectros ideológicos e renderamlhe nos seus últimos anos de vida uma série de projetos de museus e conjuntos culturais. Entre outros, destaca-se no Brasil: o Museu Nacional de Brasília (1999-2006) (parte do Conjunto Cultural da República), no qual reedita a abóbada circular que criou para o Palácio das Artes do Parque Ibirapuera, em São Paulo, onde projetou o Auditório (2002-2005) que completou o conjunto projetado por ele mesmo em 1951; e na Europa, onde além do pavilhão da Serpentine Gallery, desenhou um Auditório em Ravello (2000-2010), em Itália, e o Centro Cultural Principado de Astúrias (2006-2010), em Avilés (Espanha).

Outro exemplo do mesmo fenómeno, Paulo Mendes da Rocha também viu crescer o número de encomendas para museus nos últimos anos. Além do novo Museu Nacional dos Coches em Lisboa (2008-2015) - que contribui para consolidar a zona monumental de Belém como polo de atração turística -, o Cais das Artes de Vitória (em obras), no Estado do Espírito Santo, no Brasil, figura entre as suas maiores obras já construídas. A este arquiteto agregam-se inúmeros equipamentos culturais no Brasil, tais como o museu infantil SABINA (1999-2007) em Santo André; o Museu da Língua Portuguesa (2000-2006) e a Praça dos Museus da Universidade de São Paulo (2010 - em obras), ambos em, São Paulo; o MM Gerdau, Museu das Minas e do Metal (2006), em Belo Horizonte; e o SESC 24 de maio - Serviço Social do Comércio (2000-2017), também na capital paulista.

As questões ensejadas pelo projeto do MON, assim como pelos demais museus desenhados por Niemeyer e por outros arquitetos brasileiros provenientes da geração moderna (Mendes da Rocha, Ruy Ohtake, Décio Tozzi e Eduardo de Almeida, entre outros), colocam em debate as consequências e o legado da presença ativa de grandes mestres modernos na atualidade. Questionam também, e principalmente, a resistência e a maleabilidade dos ideais modernos no contexto contemporâneo.

\section{O Museu do Pão e o Instituto Moreira Salles: diálogos interiores}

Em paralelo à omnipresença dos mestres da modernidade, uma consistente produção vem sendo desenvolvida por uma geração de arquitetos formados principalmente a partir de 1975, com crescente atuação e visibilidade a partir da década de 1990. Entre as características distintivas dessa produção, destaca-se o forte vínculo com os princípios éticos e estéticos da arquitetura moderna brasileira, notadamente com a sua vertente paulista.

Entre as obras de museus mais publicadas entre 1985 e 2018, destacam-se os projetos do escritório paulista Brasil Arquitetura, atualmente composto por Marcelo Ferraz e Francisco Fanucci. O escritório notabilizou-se por projetar pequenos museus em cidades 
pouco conhecidas do interior do país, muito vinculados ao universo da cultura popular e comummente desenvolvidos em preexistências ou edifícios históricos. De certa forma, os seus projetos apresentam a face mais vistosa de uma tendência geral de interiorização de museus e centros culturais observada no país a partir da redemocratização.

\section{Museu do Pão, Ilópolis (Rio Grande do Sul)}

0 projeto arquitetónico do pequeno Museu do Pão (2005-2007), em Ilópolis, no Estado do Rio Grande do Sul, é exemplar da impugnação de fronteiras fixas entre o popular e o culto, estimulando a interação entre história, cultura e vida comunitária. A partir da recuperação de um moinho de grãos desativado, construído por imigrantes italianos que chegaram em massa ao Brasil entre o final do século XIX e o início do século XX, idealizou-se um centro de resgate da memória e das tradições locais, constituindo-se como um novo centro significativo da pequena cidade de Ilópolis.

Ao casarão construído em madeira de araucária, árvore típica do sul do Brasil, os arquitetos adicionaram dois volumes prismáticos em betão, vidro e madeira, dispostos ortogonalmente ao redor da antiga edificação. Num deles situa-se o museu, onde objetos de valor histórico e afetivo ajudam a contar a história da comunidade, enquanto no outro volume funciona uma escola de panificação, recuperando a tradição como algo vivo e plenamente operativo.

No mesmo sentido, ao invés de transformar o espaço do velho moinho em sala expositiva, a opção foi retomar as atividades originais de trituração de grãos de milho e trigo para a feitura de farinha. Os arquitetos criaram, dessa forma, uma arquitetura narrativa, em diálogo com a tradição construtiva local e com o seu entorno (fig. 3 e 4).

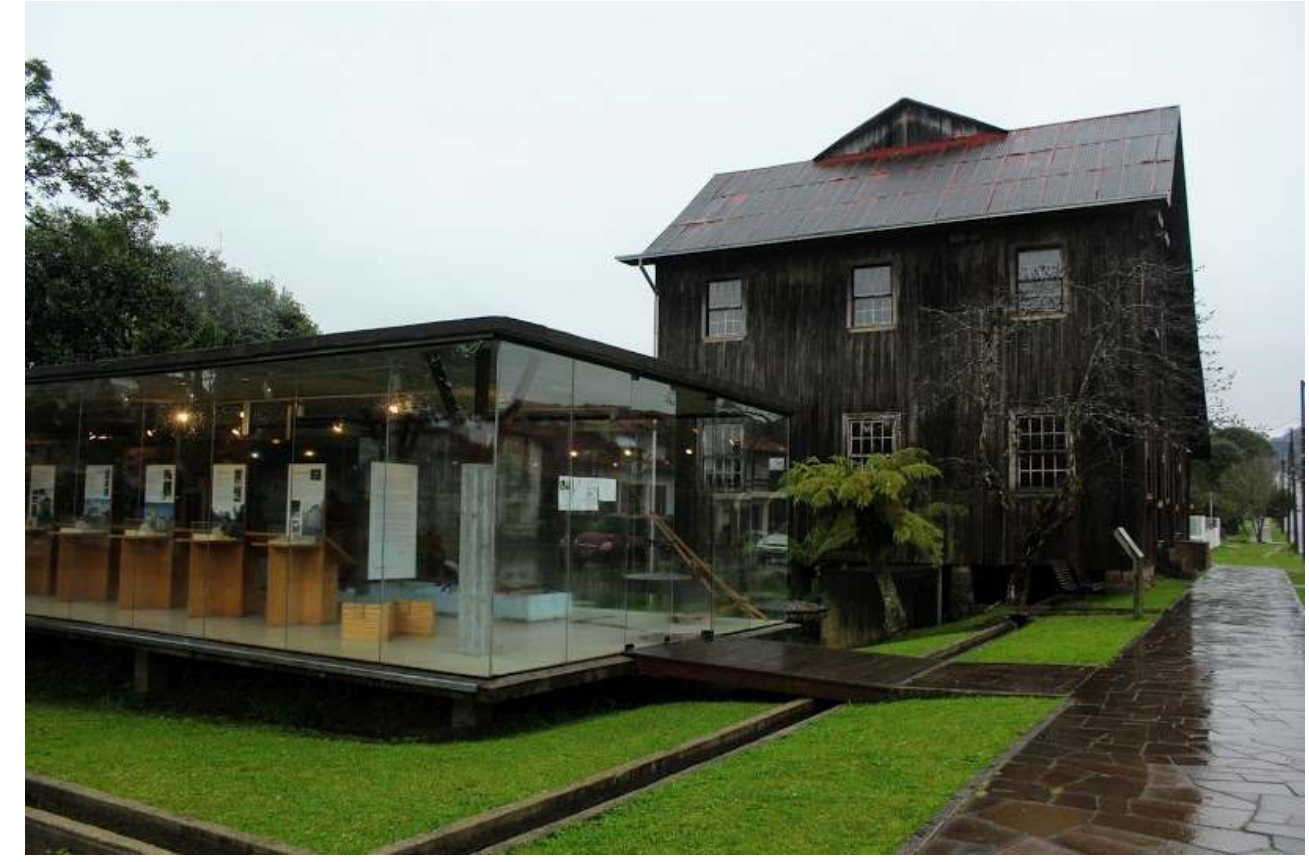

Fig. 3 - Vista frontal do Museu do Pão (Ilópolis, Rio Grande do Sul), 2018

(c) Ivo Renato Giroto 


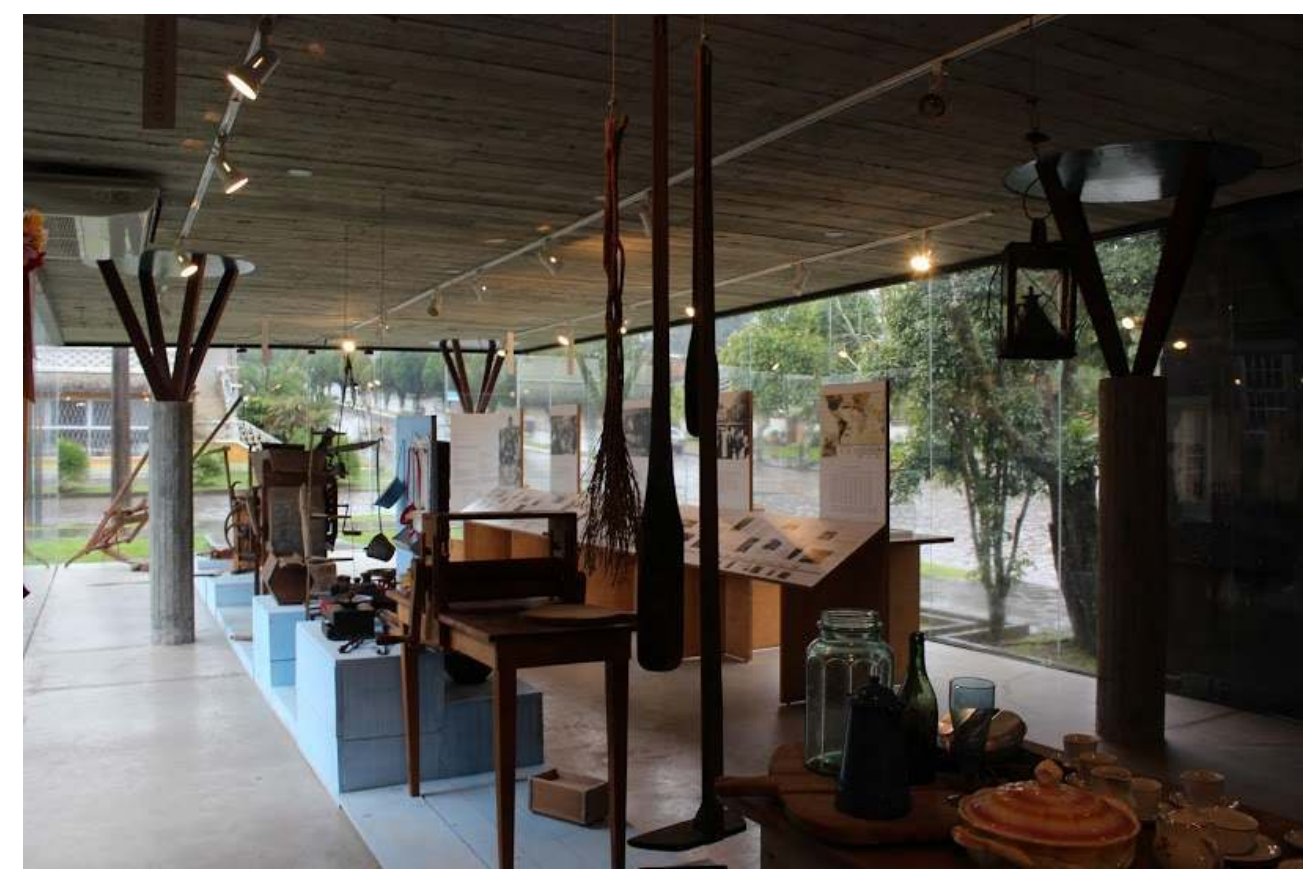

Fig. 4 - Vista da área expositiva do Museu do Pão (Ilópolis, Rio Grande do Sul), 2018

(c) Ivo Renato Giroto conceito de "presente histórico", defendido pela arquiteta Lina Bo Bardi (1914-1992) em texto de 1990, para quem o passado devia ser tratado como algo vivo, útil e passível de transformações, "libertando-se das amarras" da obrigatoriedade de manter os bens patrimoniais intocados, congelados no tempo (Bo Bardi 2009, 165). Como herança desta arquiteta ítalo-brasileira, com quem Marcelo Ferraz trabalhou durante longo tempo, o escritório Brasil Arquitetura adquiriu uma sólida experiência na conversão de bens patrimoniais em equipamentos culturais.

30 Com efeito, o Museu do Pão integra um numeroso grupo de edifícios históricos convertidos em centros culturais, uma forte tendência observada no Brasil a partir de meados da década de 1980 quando, face ao cenário instável da pós-modernidade, o acervo construído passou a ser valorizado como legado cultural a ser reutilizado (Bastos e Zein 2010, 333-347; Segawa 2014, 197). Segundo dados de 2010 do Instituto Brasileiro de Museus, 82,4\% dos 3025 museus brasileiros têm as suas sedes em edifícios originalmente concebidos para outros usos (IBRAM 2011, 100).

31 Também no caso de Lina Bo Bardi, os seus projetos herdaram o encantamento e a sensibilidade pela arte e pela cultura popular do Brasil. Na obra da arquiteta, o hibridismo de referências locais e internacionais, que caracterizou a arquitetura moderna brasileira, é marcado pela substituição da matriz barroca portuguesa pela arquitetura anónima e rústica das populações que conservam a raiz arcaica da cultura brasileira.

O Museu do Pão também reflete a diversidade e a especificidade temática, por vezes inusitada, que se tem tornado comum entre os novos museus contemporâneos no Brasil e no mundo. Entre os exemplos de maior êxito de público deste segmento, estão os recentes Museu do Futebol (2008), da autoria do arquiteto Mauro Munhoz, instalado no tradicional Estádio do Pacaembu, e o Museu da Língua Portuguesa (2006), projetado por Paulo Mendes da Rocha na histórica Estação da Luz - atualmente em reconstrução após o 
incêndio de 2015 -, ambos situados em São Paulo. A conceção de um museu específico para celebrar a temática do pão convoca relações com o museu homónimo existente desde 2002 em Seia, na região da Serra da Estrela, em Portugal.

Parte de um projeto denominado "Caminho dos Moinhos", idealizado em 2003 com a participação direta dos arquitetos, o Museu do Pão integra um grupo de seis antigos moinhos existentes ao longo do vale do rio Taquari, na serra gaúcha. A criação de rotas turístico-culturais tem-se disseminado no Brasil, indicando um processo de "museificação" que transcende o âmbito de edificações isoladas para alcançar parte do território. Além do "Caminho dos Moinhos", destaca-se a consolidação turística do "Vale dos Vinhedos", também no Estado do Rio Grande do Sul; do "Vale do Café", na região serrana do Estado do Rio de Janeiro; a "Estrada do Chocolate", por onde se planta o cacau na costa sul da Bahia; incluindo um "Caminho da Fé" no interior paulista, inspirado no milenar Caminho de Santiago de Compostela, na Europa.

\section{Instituto Moreira Salles, São Paulo}

34 Também representante e herdeira da tradição arquitetónica paulista, a nova sede do Instituto Moreira Salles (2012-2017), integra um dos territórios culturais mais significativos de São Paulo, consolidado de forma relativamente espontânea ao longo de quase três $\mathrm{km}$ da sua via mais simbólica, a Avenida Paulista. Importante centro financeiro, esta avenida, que abriga o icónico Museu de Arte de São Paulo - o MASP (1957-1968), projetado por Lina Bo Bardi -, atualmente é caracterizada pela diversidade. A partir da década de 1990, com a inauguração da Casa das Rosas, um centro de cultura instalado num palacete da década de 1930, passou a consolidar-se como eixo cultural, contando atualmente com o instituto Itaú Cultural (1991-1995), do pintor, arquiteto e urbanista Ernest Mange (1922-2005); o centro Cultural da FIESP - Federação das Indústrias do Estado de São Paulo - (1996), com intervenção de Paulo Mendes da Rocha no piso térreo do edifício-sede da instituição; a Japan House (2017), do arquiteto japonês Kengo Kuma; e mais recentemente o SESC Paulista (2018), dos arquitetos Jorge Königsberger e Gianfranco Vannucchi.

Assim como a maioria das demais instituições citadas acima, o Instituto Moreira Salles faz parte de uma série de importantes instituições culturais privadas, viabilizadas por leis de incentivo implementadas no Brasil a partir de meados da década de 1980 (Farias 2004, 75). A partir de então, inúmeras empresas privadas e estatais criaram os seus próprios centros de arte e cultura em troca de deduções de impostos, entre os quais se podem destacar aqueles vinculados a importantes instituições financeiras, como a Caixa Cultural, o Centro Cultural Banco do Brasil, o Itaú Cultural, o Santander Cultural e o próprio Instituto Moreira Salles, mantido pela família de banqueiros proprietária do grupo Itaú-Unibanco.

Fundado em 1992 e com sedes nas cidades de Poços de Caldas, Rio de Janeiro e São Paulo, o Instituto Moreira Salles possui importantes acervos de fotografia, música, literatura e i conografia.

Desenhado pelos arquitetos Vinícius Andrade e Marcelo Morettin, em diálogo com os edifícios mais icónicos da avenida Paulista, o edifício parte de um firme compromisso com a cidade, que adentra o piso térreo destinado a espaço público. 0 projeto procura reforçar e disputar as virtudes públicas da grande avenida, permeada pela diversidade de usos e de pessoas, e pela abundância de infraestruturas e de transporte. 
De facto, o projeto arquitetónico adotado nasceu tanto das condicionantes impostas pelo lote estreito, o que obrigou à verticalização do museu em sete pisos, como do diálogo com o passeio e a paisagem construída da avenida, que possui alguns dos melhores exemplares arquitetónicos de relação entre espaço público e privado, como o Conjunto Nacional (1955), do arquiteto brasileiro David Libeskind (1928-2014), a Fundação Casper Líbero (1980), da autoria do arquiteto italiano Gian Carlo Gasperini, e os já citados edifício sede da FIESP (1968), dos brasileiros Roberto Cerqueira César (1917-2003) e Luis Roberto Carvalho Franco (1926-2001), e o próprio MASP.

A compreensão da arquitetura como infraestrutura urbana e extensão do espaço público como praça coberta, atitudes típicas dos projetos desenvolvidos pelos arquitetos modernos paulistas, é novamente evocada numa praça situada no quarto andar, de onde se pode apreciar a vista para a icónica avenida. A praça elevada funciona como distribuidor funcional, tendo abaixo de si espaços como cinema/auditório e biblioteca, e acima as salas expositivas de uso público. Os andares vazios, o corte de alguns pavimentos atravessados pela escada rolante e a inclinação de volumes no interior eliminam a previsível monotonia que seria provocada pela sucessão das lajes.

o marcado caráter público e as características centrais do projeto da sede do Instituto Moreira Salles inscrevem-no numa tradição arquitetónica viva, que ainda encontra na Faculdade de Arquitetura e Urbanismo da Universidade de São Paulo o seu centro de gravidade, ancorado em figuras como João Batista Vilanova Artigas (1915-1985) e, principalmente, Paulo Mendes da Rocha (Milheiro 2006, 93).

41 Numa poética relação com o entorno, um revestimento de vidro translúcido envolve o edifício, deixando entrever de fora as silhuetas de pessoas e volumes, e filtra as imagens da cidade. A translucidez do revestimento consegue marcar a sua singularidade no entorno com subtileza, dialogando com a tipologia prismática dos prédios vizinhos, ao mesmo tempo em que deles se diferencia pela insinuação dos volumes internos independentes, revestidos pelo vidro (fig. 5 e 6 ). 


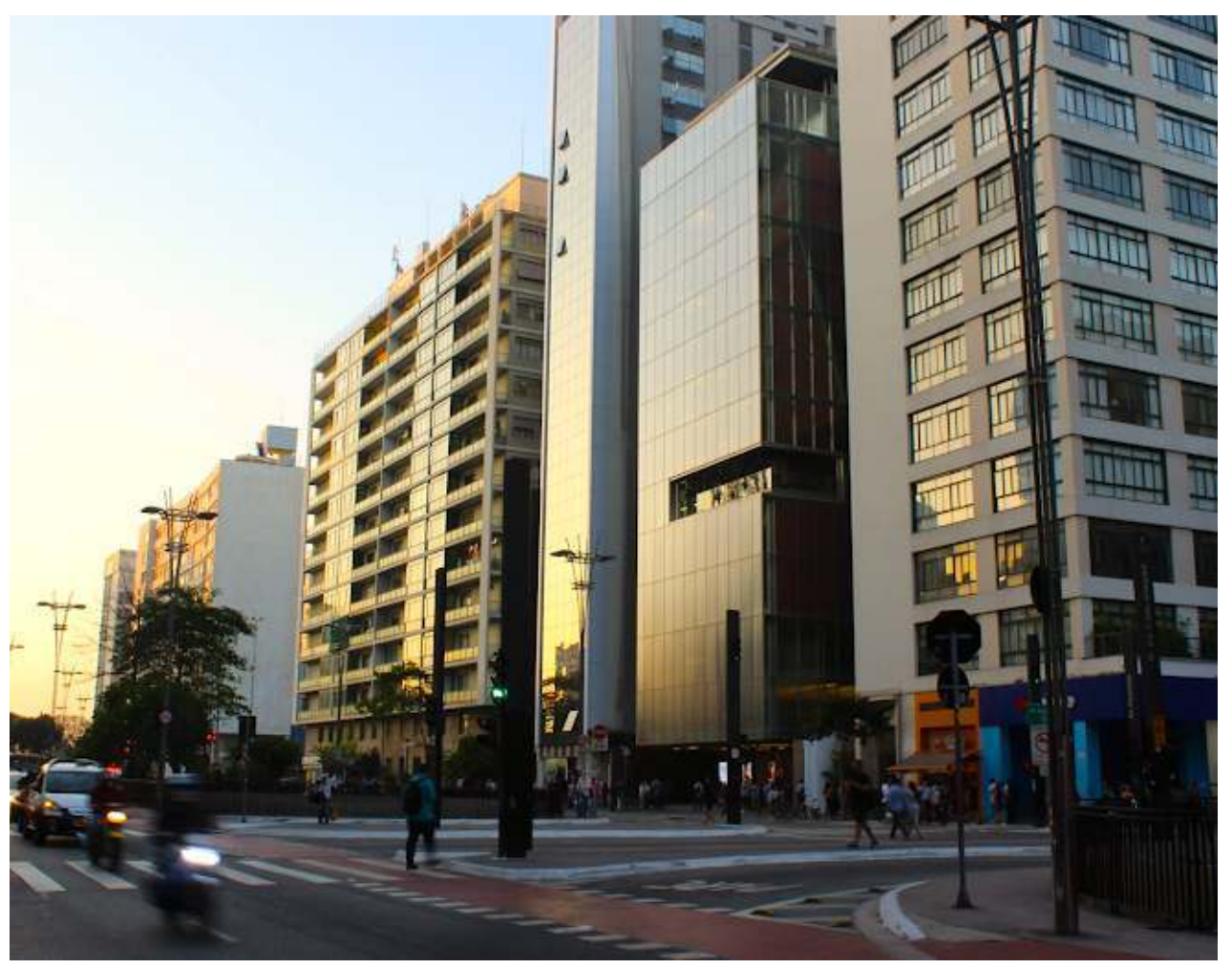

Fig. 5 - Vista frontal do Instituto Moreira Salles, São Paulo, 2018

(c) Ivo Renato Giroto

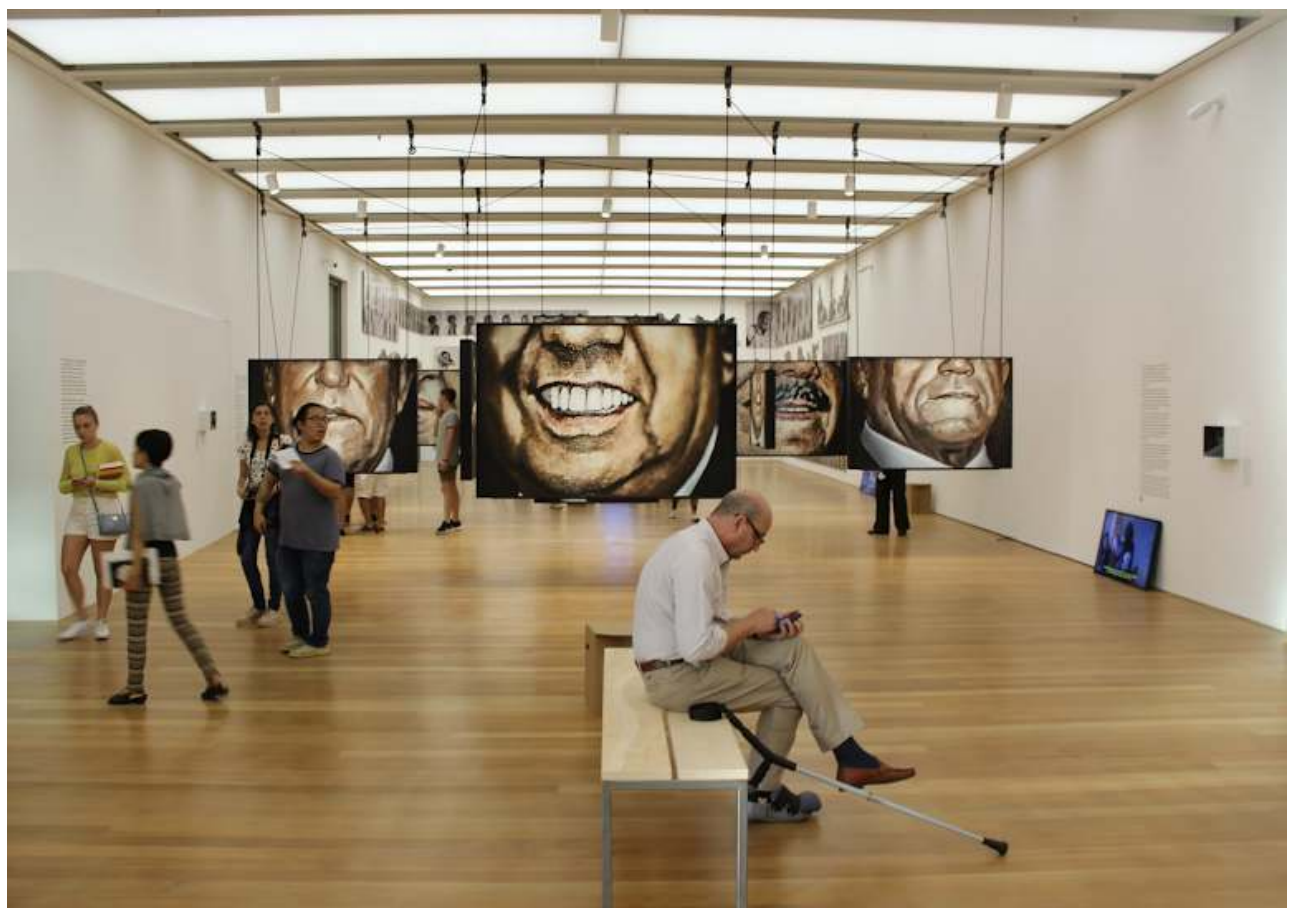

Fig. 6 - Vista da área expositiva do Instituto Moreira Salles, São Paulo, 2018 (c) Ivo Renato Giroto

O revestimento atua como mediador entre a desejada relação e o necessário isolamento entre os ambientes e ritmos radicalmente diferentes do museu e da metrópole. As imagens espectrais que acendem as formas avermelhadas por detrás do vidro foram 
buscar, segundo os arquitetos, inspiração no caráter intimista da Casa de Vidro (1932) do arquiteto francês Pierre Chareau (1883-1950) e do arquiteto holandês Bernard Bijvoet (1889-1979), em Paris.

As obras do escritório de arquitetura Andrade Morettin representam a independência e a maturidade crescentes com que os jovens arquitetos brasileiros se têm posicionado no contexto contemporâneo, agregando novas e variadas referências ao inescapável referencial moderno do país. No Instituto Moreira Salles, por exemplo, revela-se a coexistência de um modo de projetar definido pelo desenho do corte, herdeiro da arquitetura de João Batista Vilanova Artigas e de Paulo Mendes da Rocha, com uma multiplicidade de ressonâncias mais difusas e distantes, como as ousadas propostas de Rem Koolhaas e da arquitetura tecnológica de Renzo Piano e de Norman Foster.

Esse panorama plural começou a ser desenhado a partir da rutura pós-moderna que dominou os anos 1980, superada ao longo da década seguinte pelo resgate dos princípios estéticos da modernidade. No entanto, conceitos típicos da pós-modernidade mostravam que haviam conquistado um espaço definitivo na práxis arquitetónica nacional, entre estes a experimentação formal e tecnológica, a diversidade e a liberdade na manipulação de referências e heranças, bem como uma marcada posição de compromisso com o lugar (Zein 1990, 68).

\section{A Fundação Iberê Camargo e o Museu do Amanhã: diálogos exteriores}

As intervenções de arquitetos de renome internacional é outra face distintiva do atual cenário arquitetónico brasileiro, bastante autorreferente e pretensamente autónomo ao menos até à eclosão dos discursos pós-modernos a partir dos anos 1980 (Bastos e Zein 2010, 196-197; Segawa 2014, 190-191). Atraídos pela prosperidade económica da primeira década e meia do século XXI, e estimulados pela visibilidade trazida pela realização de grandes eventos desportivos, os museus desenhados por célebres arquitetos estrangeiros sugerem outros diálogos com a condição socioeconómica e cultural brasileira.

\section{Fundação Iberê Camargo, Porto Alegre}

O primeiro projeto de efetivo impacto nacional e internacional foi desenvolvido a partir de 1998 pelo arquiteto português Álvaro Siza Vieira para a nova sede da Fundação que alberga a coleção do pintor gaúcho Iberê Camargo (1914-1994), em Porto Alegre. ${ }^{2}$ Inaugurado em 2008, o edifício, implantado num terreno de uma antiga pedreira desativada nas margens do lago Guaíba, tornou-se uma das imagens referenciais da cidade.

Face a um entorno urbano rarefeito onde predomina a presença de um paredão rochoso $\mathrm{e}$ a extensão de um espelho d'água, separados por uma movimentada avenida, a conhecida habilidade do arquiteto português em integrar a arquitetura ao lugar teve de responder a outro desafio nada incomum no Brasil: criar contexto. A obra de arquitetura encaixa-se na paisagem preenchendo o vazio deixado pelas escavações da pedreira, do qual tira proveito como gerador formal de um volume fragmentado e de marcada imposição escultórica. Na prática, mais do que participar do contexto existente, Álvaro Siza Vieira realiza uma operação de construção de uma nova paisagem. 
xpressionismo formal da obra capta o espírito angustiado e complexo do trabalho do pintor Iberê Camargo, materializado na espacialidade interna labiríntica de passarelas suspensas, em contraste com a abertura e regularidade das salas expositivas. As telas do pintor possuem um caráter expressionista e sombrio que contrastam com a brancura do espaço. Talvez a escolha de Siza Vieira viesse ao encontro do artista, dado que «Iberê era um moderno, tinha em mente genéricas paredes brancas para a sua pintura» (Kiefer 2010, $\mathrm{s} / \mathrm{p})$.

A arquitetura definida pelas angulosidades e curvas plasmadas no betão branco revela um intenso diálogo com a tradição moderna brasileira, num edifício cuja extroversão formal contrasta com a contenção da maioria das obras anteriores de Siza Vieira.

$\mathrm{Na}$ inauguração da sede da Fundação Iberê Camargo, o arquiteto e investigador Jorge Figueira entreviu o início de uma nova fase na relação entre as culturas arquitetónicas do Brasil e de Portugal, cuja devolutiva se encontra na obra para o Museu dos Coches, do arquiteto Mendes da Rocha. Para além de uma representação da época dos arquitetosestrela, ambos significam o aprofundamento de um diálogo antigo e tortuoso (Figueira 2008a, 16).

O encontro entre os dois países encerra um significado histórico que potencializa uma narrativa arquitetónica continuamente atravessada pela lembrança das curvas e das rampas suspensas de Niemeyer, pela constrita espacialidade medieval europeia, pelas passarelas de Lina Bo Bardi no SESC Pompeia (1977-1986), por evocações ao trabalho do arquiteto finlandês Alvar Aalto (1898-1976), entre inúmeras contaminações formais que se misturam à brancura do betão armado, símbolo da tradição moderna brasileira (fig. 7 e 8).

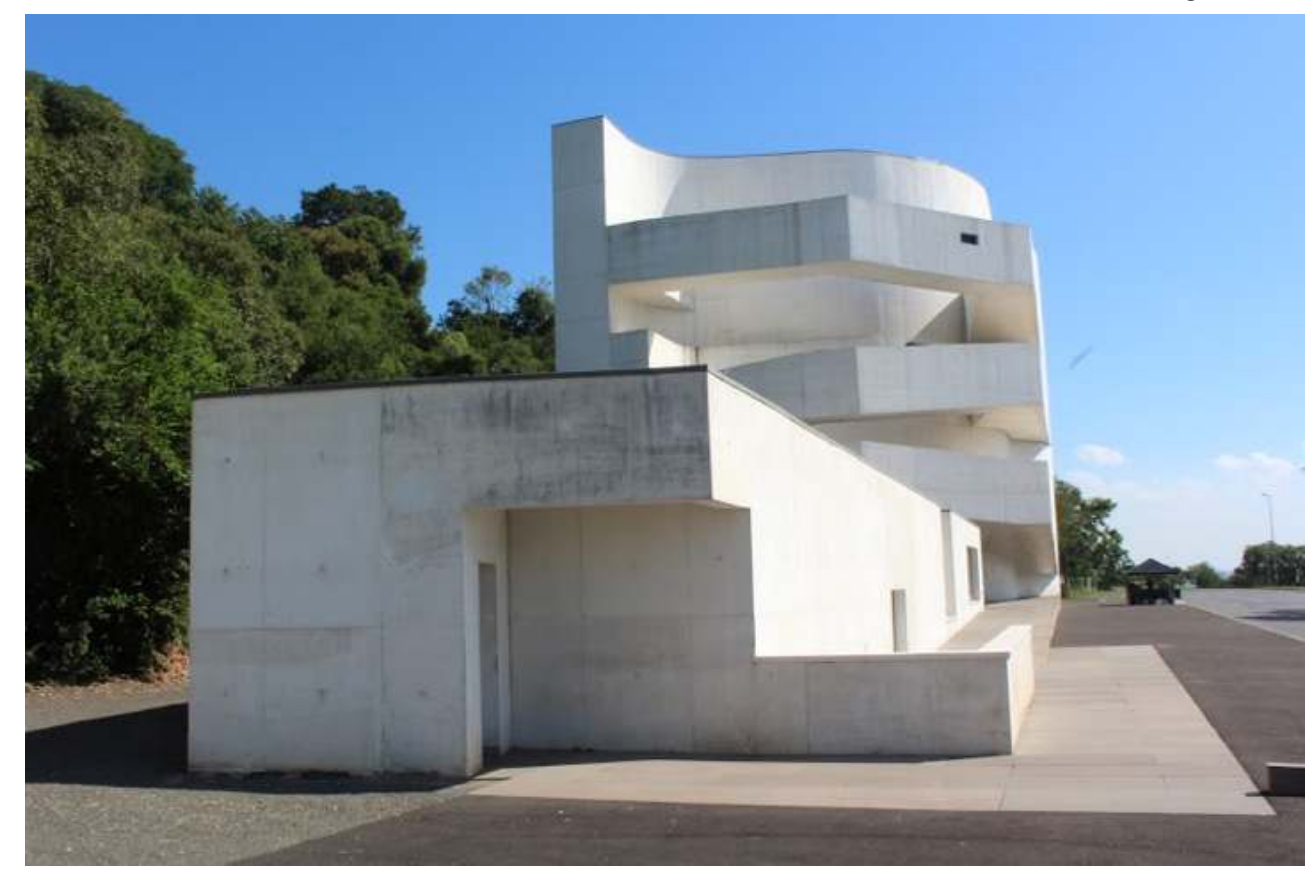

Fig. 7 - Vista externa da Fundação Iberê Camargo, Porto Alegre, 2018

(C) Ivo Renato Giroto 


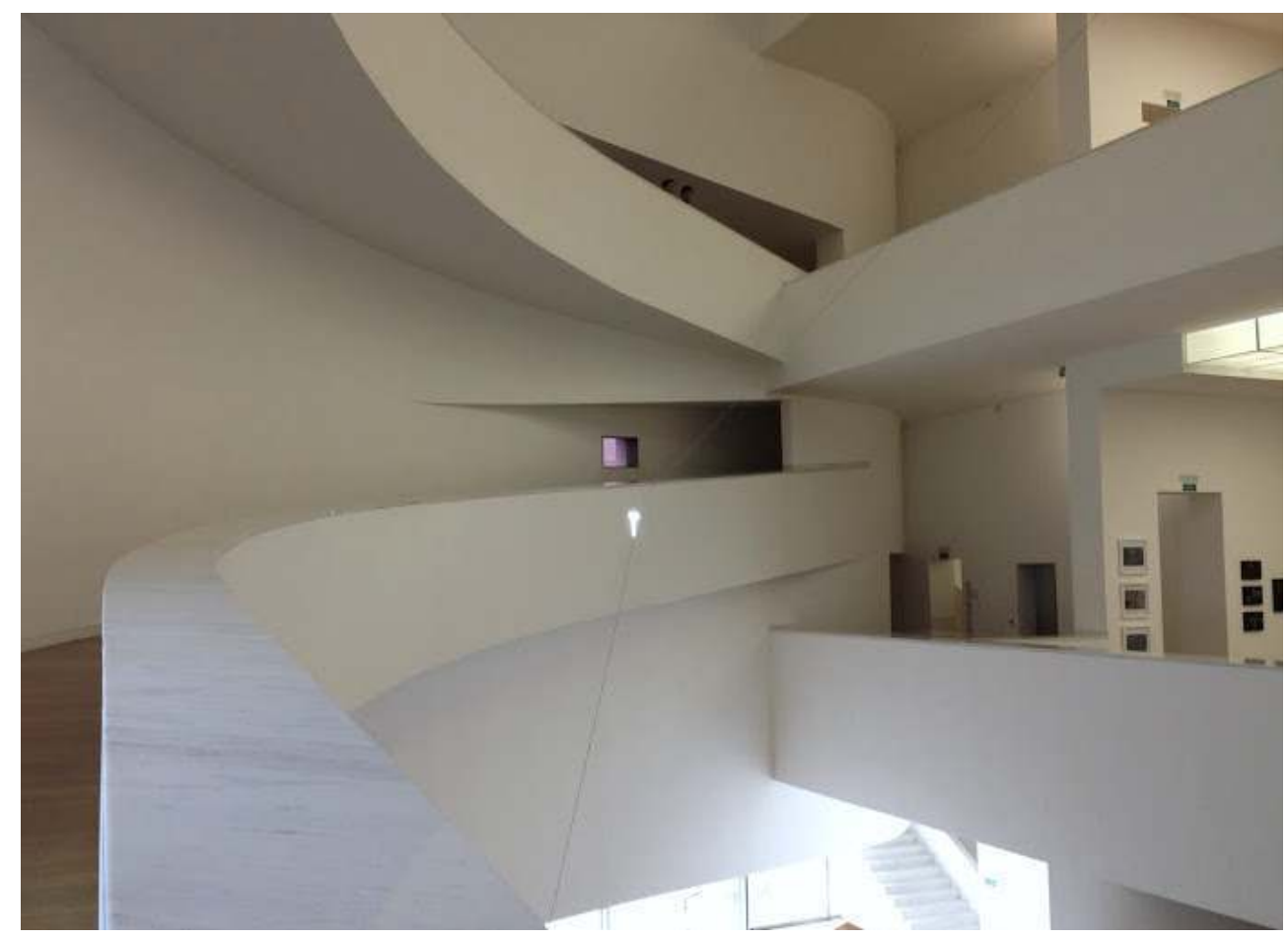

Fig. 8 - Vista das rampas que conformam parte da espacialidade interna da Fundação Iberê Camargo, Porto Alegre, 2018

(c) Ivo Renato Giroto

52 Nas obras fora de Portugal Álvaro Siza Vieira procura adquirir "sotaques" e linguagens alheias, algo que Jorge Figueira atribui a uma suposta capacidade portuguesa de despersonalizar-se - à maneira do que fazia o poeta Fernando Pessoa com os seus heterónimos (Figueira 2008b, 128). Nesse intento de aclimatar-se a ambientes e culturas que lhe são estranhas, o arquiteto espanhol Rafael Moneo reconhece uma estratégia baseada na manipulação de excessos e extravagâncias, que transformam a arquitetura em narração, na qual podem identificar-se figuras e personagens que dialogam: «Siza em terra estranha é muito mais esquemático do que na própria» (Moneo 2008, 218).

Efetivamente, a Fundação Iberê Camargo da autoria de Álvaro Siza Vieira faz parte de um conjunto de obras construídas fora da Península Ibérica de grande expressividade simbólica e caráter narrativo, como por exemplo o Pavilhão Álvaro Siza (2005-2006) e o Museu Mimesis (2006-2009), ambos situados na Coreia do Sul.

O diálogo entre arquitetura e arte, arquiteto e artista, presente na Fundação Iberê Camargo ilustra uma exceção no panorama brasileiro, no qual ainda são raros os museus monográficos dedicados à obra de um só artista. Ao contrário do museu enciclopédico, a sede da Fundação Iberê Camargo enquadra-se num contexto global de busca por uma intensidade experiencial que Thomas Krens, então diretor da Fundação Solomon R. Guggenheim, advogava para os novos museus a partir da década de 1990. Este novo tipo de museu "sincrónico" deveria evocar a experiência do Minimalismo na exploração de uma fruição artística profundamente vinculada com o espaço onde as obras estão expostas (Krauss 1990, 7).

A referência a Thomas Krens evoca outro marco da intervenção de arquitetos de renome internacional no Brasil, aquando da tentativa frustrada da instalação de uma extensão do Guggenheim no Rio de Janeiro (2001), com projeto de arquitetura assinado por Jean 
Nouvel. Também na capital carioca, a este seguiu-se o projeto da Cidade das Artes (2002-2013), da autoria do arquiteto francês Christian de Portzamparc, e a inacabada nova sede do Museu da Imagem e do Som (2009-), do escritório de arquitetura americano Diller Scofidio + Renfro.

\section{Museu do Amanhã, Rio de Janeiro}

O Museu do Amanhã, um projeto do arquiteto Santiago Calatrava (2009-2015), construído na zona portuária do Rio de Janeiro, pode ser considerada a primeira tentativa bemsucedida de instalação, no Brasil, de um museu orientado pelo marketing, à maneira dos Guggenheim idealizados por Thomas Krens. De caráter informativo, o museu não possui acervo físico e aposta em exposições virtuais e na interatividade como chamarizes para a atração de turistas, que passaram a frequentar a região após o processo de revitalização urbana empreendido pela prefeitura da cidade desde 2011.

Pousado como uma grande escultura sobre o Píer Mauá, um braço de terra que parte da praça homónima sobre a Baía de Guanabara, o seu volume horizontal alongado termina em grandes balanços nas extremidades, o que confere leveza à massa edificada. A relativa desconexão do cais da trama urbana circundante e a sua especial condição paisagística, amplificam o potencial icónico do edifício do museu.

A declarada intenção de refletir o genius loci do Rio de Janeiro não parece ter rebatimento formal numa obra que claramente deriva da conjunção da linguagem pessoal do arquiteto com as condicionantes do sítio onde está implantada. A arquitetura cinemática, que faz o edifício movimentar-se ao longo do dia, através de estruturas metálicas móveis acionadas por energia solar, parece ser mais um exercício da sua habilidade em manipular a mecânica das estruturas para finalidades estéticas que é uma referência a lugares-comuns sobre o Brasil, como a natureza e o carnaval como um «monumento à beleza, ao movimento e à música» (Calatrava 2012, s/p) (fig. 10 e 11).

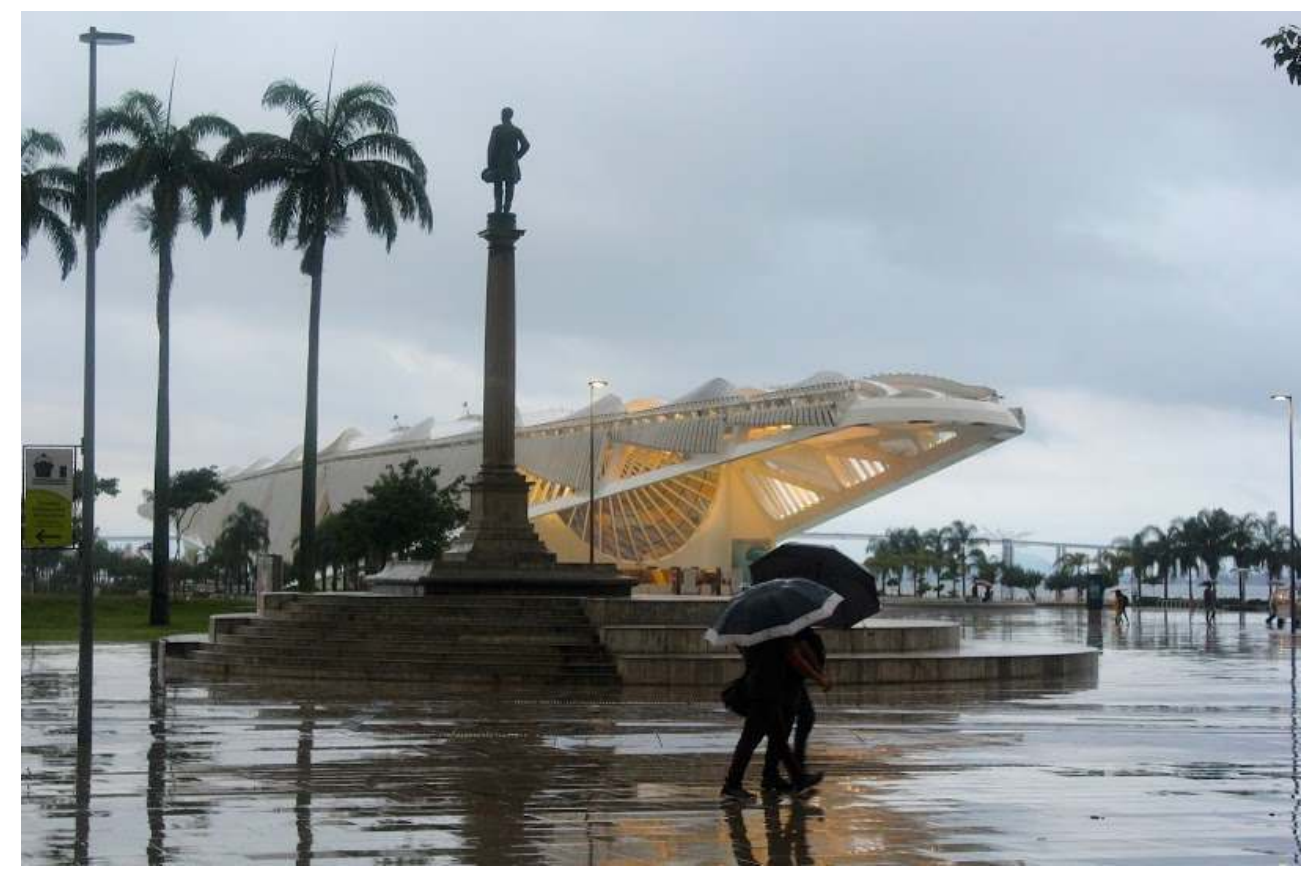

Fig. 10 - Vista frontal do Museu do Amanhã, Rio de Janeiro, 2018

(C) Ivo Renato Giroto 


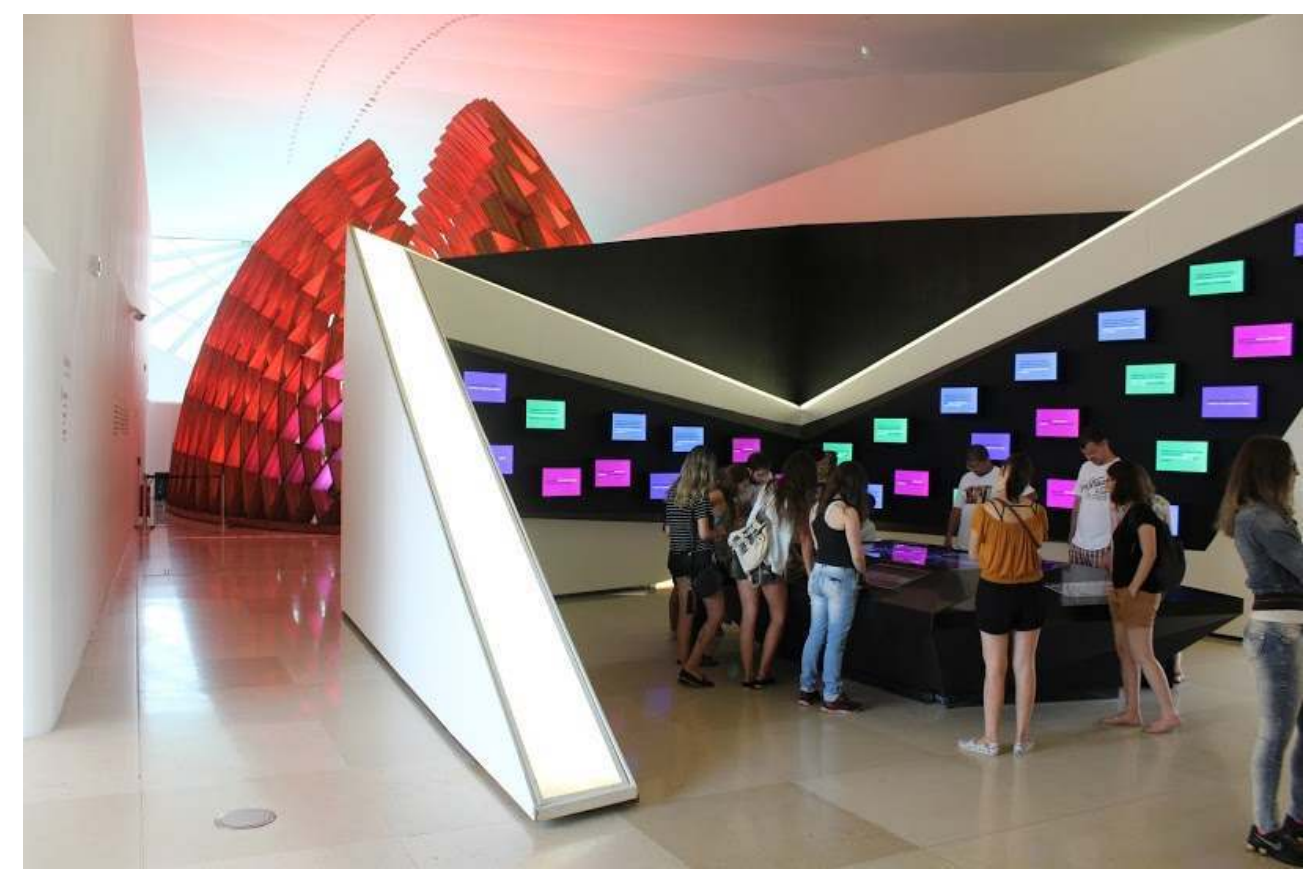

Fig. 11 - Vista interna do Museu do Amanhã, Rio de Janeiro, 2018

(c) Ivo Renato Giroto

59 Os setores expositivos, que tratam do futuro do planeta e da sustentabilidade, são dispostos independentemente ao longo de um amplo pavilhão longitudinal. Santiago Calatrava justifica a opção pavilhonar: «A natureza temporária das exposições nos fez implementar uma estrutura no interior do edifício com uma simplicidade de entendimento, para permitir essa versatilidade do museu» (Tamaki 2016, 29).

Criadas a partir de recursos audiovisuais e interativos que não contaram com a participação direta do arquiteto, as áreas de exposição tiveram conceção museográfica de Ralph Appelbaum, com curadoria de Luiz Alberto Oliveira. A premissa virtual que orienta a museografia encontra precedentes no Brasil nos já citados Museu da Língua Portuguesa e no Museu do Futebol.

61 Imagem mais espetacular do projeto urbano "Porto Maravilha", o Museu do Amanhã divide a Praça Mauá com o Museu de Arte do Rio (2013), conhecido pelo acrónimo MAR, projetado pelo escritório carioca Bernardes \& Jacobsen, integrando três edifícios preexistentes - um palacete eclético, um edifício modernista e um terminal de autocarros desativado. Os dois museus passaram a integrar e a reforçar um distrito cultural que conta nas suas imediações com o Centro Cultural Banco do Brasil, o Centro Cultural dos Correios e a Casa França-Brasil, todos os casos adaptados a partir de edifícios tombados pelos órgãos tutelares do património no Brasil.

62 A transformação de áreas urbanas em distritos culturais é uma característica distintiva que combina política urbana e cultural no Brasil contemporâneo. Muito relacionados com o resgate de áreas centrais degradadas, com processos de conversão de edifícios históricos em equipamentos culturais, a criação destes distritos encontra precedentes em experiências europeias levadas a cabo a partir dos anos 1970, cujos resultados, por vezes questionáveis, acabaram por construir estéreis teatros da memória voltados essencialmente para o consumo turístico (Arantes 2015, 144-145). 
63 A construção dos dois museus - o Museu do Amanhã e o MAR - estava intimamente ligada aos projetos de preparação da cidade do Rio de Janeiro para os Jogos Olímpicos de 2016, que teve na experiência de Barcelona 1992 o seu principal modelo de referência. 0 corredor cultural da zona portuária carioca emula as intervenções idealizadas pelos arquitetos Lluís Clotet e Oscar Tusquets que transformaram o então degradado bairro barcelonês do Raval, com a criação de um eixo cultural, através da requalificação de edifícios existentes e a construção de novos equipamentos, tais como o Museu d'Art Contemporani de Barcelona (MACBA), o Centre de Cultura Contemporània de Barcelona (CCBB) e o Centro Pati Manning.

64 Também no início da década de 1990 se consolidou o "Triângulo da Arte" de Madrid, com a inauguração do Museo Nacional Thyssen-Bornemisza, ao lado do Museo Nacional del Prado e do Museo Nacional - Centro de Arte Reina Sofía. Entre muitos outros, destaca-se ainda a consolidação do MuseumsQuartier de Viena (Áustria), entre 1998 e 2001, constituindo um dos maiores complexos de arte e cultura do mundo, englobando mais de 60 equipamentos culturais.

65 Sempre polémica, a transformação de bairros centrais em polos de atividade cultural tem sido analisada a partir de visões mais positivas, relacionadas com a capacidade de geração de empregos e de crescimento económico (Markusen e Schrock 2006), ou marcadamente negativas, vinculadas ao seu potencial gentrificador e segregacionista (Harvey 2005; Peck 2005).

66 No Brasil, a par com a operação urbana da zona portuária do Rio de Janeiro, destaca-se a criação, a partir de 2010, de um circuito cultural no entorno da Praça da Liberdade, em Belo Horizonte, que conta com 15 instituições culturais instaladas em edifícios ecléticos de valor histórico.

67 Em São Paulo não se obteve muito êxito com a implantação de um eixo cultural na degradada região da Luz, área central da cidade. Com um público de perfil muito diferente da realidade socioeconómica da região, o conjunto de edifícios ecléticos construídos entre o final do século XIX e o início do século XX, como a Pinacoteca do Estado - obra do arquiteto paulista Ramos de Azevedo (1851-1928) com requalificação arquitetónica de Paulo Mendes da Rocha em 1998 -, a Estação Pinacoteca, o Memorial da Resistência, o Museu de Arte Sacra, o Museu da Língua Portuguesa e a Sala São Paulo destinada a concertos de música clássica - demonstram que a cultura isoladamente não é capaz de operar milagres urbanísticos e sociais.

\section{Conclusão}

Com a análise das cinco obras apresentadas neste artigo procurou-se sintetizar o rico panorama desenhado pela arquitetura de museus no Brasil do início deste século. Cada uma das obras referidas permite compreender de forma mais ampla as várias questões que caracterizam as especificidades do contexto brasileiro, bem como as questões mais gerais que se colocam às instituições museais no alvorecer do terceiro milénio.

Passada a euforia dos grandes eventos, a chegada de uma crise económica e política que assola o Brasil desde 2013 parece ter refreado bruscamente a entrada do país na famigerada "era dos museus", supostamente indicativa de uma condição socioeconómica privilegiada no concerto global das nações. O recente incêndio que consumiu o Museu Nacional do Rio de Janeiro em setembro de 2018 denunciou que, enquanto obras 
faraónicas eram levantadas por arquitetos-estrela, instituições importantes eram há muito tempo negligenciadas.

Da arquitetura mais espetacular à intervenção mais simples e rigorosa; da arte erudita como produto de consumo de massas à valorização da vida quotidiana; da arquitetura que procura protagonismo para o edifício que contribui para a cidade, a arquitetura de museus no Brasil perspetiva múltiplos olhares no séc. XXI. Resta aguardar pelos anos vindouros para analisar que lições poderão ser inferidas quanto ao impacto de todas estas experiências.

71 Agradecimentos: Fundação de Amparo à Pesquisa do Estado de São Paulo (FAPESP), processo 2016/21108-2.

\section{BIBLIOGRAFIA}

Arantes, Otília Beatriz Fiori. 2015. O Lugar da Arquitetura Depois dos Modernos. 3. ${ }^{\mathrm{a}}$ ed. São Paulo: EDUSP - Editora da Universidade de São Paulo.

Bardi, Lina Bo. 2009. “Uma Aula de Arquitetura." In Lina por Escrito: Textos Escolhidos de Lina Bo Bardi, organizado por Silvana Rubino, e Marina Grinover, 162-176. São Paulo: Cosac Naify.

Bastos, Maria Alice Junqueira, e Ruth Verde Zein. 2010. Brasil: Arquiteturas Após 1950. São Paulo: Perspetiva.

Bruand, Yves. 2002. Arquitetura Contemporânea no Brasil. 4. ${ }^{a}$ ed. São Paulo: Perspetiva.

Calatrava, Santiago. 2012. “Entrevista” (por Pedro Rivera). Arquitetura e Urbanismo, ano 27, edição 220, julho de 2012. http://au17.pini.com.br/arquitetura-urbanismo/220/artigo262129-2.aspx

Diez, Fernando. 2009. “Oscar Niemeyer - Além da Arquitetura.” In Tributo a Niemeyer, organizado por Christian de Portzamparc, et al., 32-36. Rio de Janeiro: Viana \& Mosley.

Farias, Agnaldo. 2004. "A Arquitetura dos Novos Museus e Alguns de seus Aspetos Contraditórios." In Seminário Internacional "Museus e Cidades"/Livro do Seminário Internacional, organizado por Ceça Guimaraens, Carlos Kessel, e Afonso Carlos Marques dos Santos, 67-80. Rio de Janeiro: Museu Histórico Nacional.

Figueira, Jorge, ed. 2008b. Álvaro Siza. Modern Redux. [Catálogo da Exposição]. São Paulo: Cosac Naify.

Figueira, Jorge. 2008a. “Um Mundo Coral.” In Fundação Iberê Camargo: Álvaro Siza, organizado por Flávio Kiefer et al., 126-138. São Paulo: Cosac Naify.

Harvey, David. 2005. “El Arte de la Renta: La Globalización y la Mercantilización de la Cultura.” In Capital Financiero, Propiedad Inmobiliaria y Cultura, 29-58. Barcelona: Museu d'Art Contemporani de Barcelona.

Herkenhoff, Paulo. 2008. Museu Oscar Niemeyer: Curitiba, Paraná, Brasil, 2003 a 2007. Curitiba: Museu Oscar Niemeyer.

IBRAM. 2011. Museus em Números/Instituto Brasileiro de Museus. Vol. 1. Brasília: Instituto Brasileiro de Museus (IBRAM). 
Kiefer, Flávio. 2010. “Fundação Iberê Camargo - Porto Alegre - RS, Álvaro Sisa Vieira.” Mdc. Revista de Arquitetura e Urbanismo, setembro 12. https://mdc.arq.br/2010/12/07/fundacao-iberecamargo-porto-alegre-rs/

Krauss, Rosalind. 1990. “The Cultural Logic of the Late Capitalist Museum.” October, vol. 54 (Autumn): 3-17.

Mahfuz, Edson. 2010. “O Clássico, o Poético e o Erótico: Método, Contexto e Programa na Obra de Oscar Niemeyer." In Textos Fundamentais sobre História da Arquitetura Moderna Brasileira, organizado por Abílio Guerra, vol. 2, 279-298. São Paulo: Romano Guerra Editora.

Markusen, Ann, e Greg Schrock. 2006. "The Artistic Dividend: Urban Artistic Specialisation and Economic Development Implications.” Urban Studies 43 (10): 1661-1686.

Milheiro, Ana Vaz. 2006. “Coletivo: A Invenção do Clássico.” In Coletivo - Arquitetura Paulista Contemporânea, organizado por Ana Luiza Nobre, Ana Vaz Milheiro, e Guilherme Wisnik, 86-97. São Paulo: Cosac Naify.

Moneo, José Rafael. 2008. Inquietação Teórica e Estratégia Projetual na Obra de Oito Arquitetos Contemporâneos. São Paulo: Cosac Naify.

Montaner, Josep Maria. 2003. Museos para el siglo XXI. Barcelona: Gustavo Gili.

Peck, Jamie. 2005. "Struggling with the Creative Class." International Journal of Urban and Regional Research vol. 29 (4): 740-770.

Segawa, Hugo. 2014. Arquiteturas no Brasil 1900-1990. São Paulo: Edusp.

Segre, Roberto. 2003. Arquitetura Contemporânea Brasileira. Rio de Janeiro: Viana \& Mosley. Tamaki, Luciana. 2016. “Novo Marco na Baía.” Arquitetura e Urbanismo, janeiro de 2016, 24-33. Zein, Ruth Verde. 1990. “No Século XXI, Fim das Utopias ou sua Realização?” Projeto 129 (jan./ fev.): 68-72.

\section{NOTAS}

1. Levantamento feito no contexto da pesquisa de pós-doutorado do autor, em andamento na Universidade de São Paulo, com o apoio da Fundação de Amparo à Pesquisa do Estado de São Paulo.

2. A Fundação Iberê Camargo foi criada em 1995, sendo a atual sede inaugurada em maio de 2008.

\section{RESUMOS}

Desde o início do século XXI, assiste-se no Brasil a um sensível aumento no número e na visibilidade de novos museus. No diálogo entre arquitetura e arte, os arquitetos têm desempenhado um papel preponderante, ora contribuindo para a valorização mútua, ora desequilibrando o debate a favor das suas criações. Este artigo procura ilustrar o rico panorama desenhado pela arquitetura de museus brasileiros construídos a partir do ano 2000, colocando em evidência a pluralidade de desafios e de tendências, assim como as relações culturais e 
geracionais que caracterizam este contexto. A partir de um primeiro levantamento, selecionou-se para análise cinco obras arquitetónicas destinadas a espaços museológicos, considerando a sua importância e repercussão: o Museu Oscar Niemeyer (2002), em Curitiba, da autoria de Oscar Niemeyer; o Instituto Moreira Salles (2017), em São Paulo, projetado por Andrade Morettin; o Museu do Pão (2007), em Ilópolis (Rio Grande do Sul), desenhado pelo escritório Brasil Arquitetura; a sede da Fundação Iberê Camargo (2008), em Porto Alegre, da autoria de Álvaro Siza Vieira; e o Museu do Amanhã (2015), no Rio de Janeiro, concebido por Santiago Calatrava. Neste início de século destaca-se a peculiar convivência entre museus projetados por arquitetos provenientes de diferentes gerações e contextos culturais diversos. Ícones da arquitetura moderna brasileira dividiram espaço com arquitetos formados a partir do último quartel do século XX, e juntos assistiram a um conjunto de intervenções no Brasil de arquitetos de renome internacional.

Since the beginning of the 21st century, Brazil has experienced a significant increase in the number and visibility of new museums. In the dialogue between architecture and art, architects have played a preponderant role, sometimes contributing to mutual appreciation, sometimes unbalancing the debate in favor of their creations. This article illustrates the rich panorama designed by the Brazilian museum architecture since 2000, highlighting the plurality of challenges and trends, and the web of cultural and generational relations that characterize such panorama. From a larger sample, five case studies are analysed, considering their importance and impact: Museu Oscar Niemeyer (2002), in Curitiba, by Oscar Niemeyer; Instituto Moreira Salles (2017), in São Paulo, by Andrade Morettin; Museu do Pão (2007), in Ilópolis (Rio Grande do Sul), by Brasil Arquitetura; Fundação Iberê Camargo (2008), in Porto Alegre, by Álvaro Siza Vieira; and Museu do Amanhã (2015), in Rio de Janeiro, by Santiago Calatrava. In this overview, stands out the peculiar coexistence between museums designed by architects from different generations and different cultural contexts. Icons of modern Brazilian architecture shared space with architects trained from the last quarter of the twentieth century, and together they witnessed a series of interventions in Brazil by internationally renowned architects.

\section{ÍNDICE}

Keywords: museum architecture

Palavras-chave: arquitetura de museus, Museu Oscar Niemeyer, Museu do Pão, Instituto Moreira Salles, Fundação Iberê Camargo, Museu do Amanhã

\section{AUTOR}

\section{IVO RENATO GIROTO}

Atualmente desenvolve pesquisa de pós-doutorado sobre os equipamentos culturais brasileiros do século XXI na Faculdade de Arquitetura e Urbanismo da Universidade de São Paulo (2017-2018), no Brasil, com o apoio da Fundação de Amparo à Pesquisa do Estado de São Paulo. Possui mestrado e doutorado em Teoria e História da Arquitetura pela Universidade Politécnica da Catalunha (2014), em Espanha, e graduação pela Universidade Estadual de Londrina (2004), no Brasil. Foi coordenador pedagógico nacional e professor da Universidade Estácio de Sá do Rio de Janeiro, entre 2012 e 2016. Desenvolve pesquisa em arquitetura moderna e contemporânea brasileira e ensino de arquitetura e urbanismo.

Departamento de História e Estética do Projeto, Faculdade de Arquitetura e Urbanismo da Universidade de São Paulo, Rua do Lago, 876, 05508-080, São Paulo, Brasil, igiroto@gmail.com 